\title{
Violência e memória: uma leitura do romance $O$ continente, de Erico Verissimo
}

\author{
Violence and memory: a reading O continente romance, \\ by Erico Verissimo
}

\author{
LAÍSA VERONEZE BISOL \\ LUANA TEIXEIRA PORTO \\ Universidade Regional Integrada do Alto Uruguai e das Missões - Frederico Westphalen - Rio Grande do Sul - Brasil
}

a

\begin{abstract}
Resumo: Este artigo analisa a representação da violência no romance $O$ continente, primeira parte da trilogia $O$ tempo e o vento, de Erico Verissimo a fim de ampliar o debate acerca dos diálogos entre literatura e sociedade no Brasil e refletir sobre o sentido e a função social de narrativas que problematizam a violência no contexto histórico-social-político-cultural do Brasil. Através deste estudo, é discutida também a perspectiva de memória sócio-histórica construída por este discurso ficcional. Com base na análise da narrativa, notamos que a abordagem da violência no texto examinado permite uma releitura atualizada do passado e propõe uma dupla percepção sobre violência e guerra, uma amparada numa "naturalização" da violência e outra em seu questionamento, o que amplia o valor ético e estético do romance de Verissimo.
\end{abstract}

Palavras-chave: O Continente; Violência; Memória

\begin{abstract}
This article analyzes the portrayal of violence in the novel $O$ continente, first part of the trilogy $O$ tempo e o vento, Erico Verissimo in order to broaden the debate about the dialogue between literature and society in Brazil and reflect on the meaning and social function narratives that question the violence in the historical -social -political-cultural context of Brazil . Through this study, it is also discussed the prospect of socio- historical memory built by this fictional discourse. Based on the analysis of the narrative, we note that the approach to violence in the examined text allows an updated last rereading and proposes a dual perception of violence and war , one supported a " naturalization " of violence and the other in his questioning, which extends the ethical and aesthetic value of Verissimo 's novel.
\end{abstract}

Keywords: The Continent; Violence; Memory

\section{Considerações iniciais}

A história social brasileira poderia ser contada através da presença da violência, que, desde o período de colonização, passando pelo período da escravidão e da Ditadura Militar até chegar ao tempo contemporâneo, assola a vida social do país, desestabiliza relações entre sociedade e Estado, promove desarmonia coletiva. Associadas à violência, outras perspectivas temáticas contribuem para contar a história de nosso país, como o exercício do autoritarismo e a visão sombria da vivência em um espaço afeito a diversas formas de desatenção a direitos humanos, o que tem sido revelado tanto em estudos acadêmicos das Ciências Sociais quanto problematizado nas artes. Tanto numa área como na outra, interessa compreender a violência como fenômeno social e como objeto de representação em diferentes campos do saber, e, nessa linha de raciocínio, podemos discutir a literatura brasileira.

No caso específico de nossa literatura, em diferentes momentos histórico-sociais, diferentes autores construíram uma leitura da realidade violenta de nosso cenário, construindo textos com diferentes tons ou tendências: a) acentuando ora horror dos conflitos, sejam elas entre grupos sociais ou entre Estado e sociedade civil ou no seio da própria sociedade, como demonstram poemas como "Nosso tempo" e "Os ombros suportam o mundo", de Carlos Drummond de Andrade; b) registrando a prática da violência como comportamento "natural" e legitimado no contexto brasílico, como atestam ainda na primeira metade do século XX contos de João Simões Lopes Neto, dos quais "O Nego Bonifácio" e "Melancia- Coco verde" 
são exemplares, e no século XXI narrativas de Beatriz Bracher, como o conto "João"; c) questionando causas e consequências da violência na constituição dos sujeitos ou na formação da estrutura social, como denunciam contos e romances de vários autores, como Caio Fernando Abreu em narrativas curtas como "Os sobreviventes" e "O mar mais longe que eu vejo" e Raduan Nassar no romance "A lavoura arcaica".

Esses exemplos mostram que a temática da violência é recorrente em textos literários de nossos escritores, mesmo que sua abordagem não se realize sempre de forma direta ou evidente ao leitor. Essa percepção foi registrada por Jaime Ginzburg (2012), para quem é possível narrar a história da literatura brasileira com base na perspectiva da violência. Para isso, de acordo com o crítico, é preciso abandonar "a tradição nacionalista idealista, com a submissão ao colonialismo, a historiografia evolutiva e a noção de progresso" (p. 13) e conjugar análise literária que equilibre observação temática e formal. Nessa mesma linha de raciocínio, Tânia Pellegrini (2005) destaca ser a violência uma prática constitutiva da nossa cultura brasileira e, por estar arraigada no país, as obras artísticas, independentemente de sua natureza, abordam-na "como um elemento fundador a partir do qual se organiza a própria ordem social e, como consequência, a experiência criativa e a expressão simbólica, aliás, como acontece com a maior parte das culturas de extração colonial" (p. 134).

Considerando isso, este trabalho discute interpretações e/ou problematizações acerca da violência propostas por textos literários a fim de ampliar o debate acerca dos diálogos entre literatura e sociedade no Brasil e refletir sobre o sentido e a função social de narrativas que problematizam a violência no contexto histórico-socialpolítico-cultural do Brasil. Na impossibilidade de abordar um conjunto vasto de textos literários que consideramos importantes para a abordagem da violência, tendo-se em vista os limites de extensão deste artigo, elegemos como objeto de análise a obra $O$ tempo e o vento, de Erico Verissimo, obra formada por três romances, $O$ continente, $O$ retrato e $O$ arquipélago, os quais têm como pano de fundo acontecimentos e histórias relativas ao processo de formação do Rio Grande do Sul, remontando o período de 1745 a 1945, o que possibilita verificar a construção de uma memória sobre esse tempo histórico através da obra. Restringimos a abordagem ao primeiro romance da trilogia, $O$ continente, pelo fato de que este romance inaugura na trilogia uma percepção que nos interessa criticamente: a abordagem da violência como algo intrínseco ao comportamento do homem gaúcho engajado na formação do Estado e também algo que é questionado por algumas personagens, como mulheres e o padre de Santa Fé, o que, por um lado, expõe uma "naturalização" da violência, e, por outro, provoca o seu próprio questionamento ao contrapor uma perspectiva afirmativa da violência a uma possível condenação de sua prática. Essa dupla perspectiva nesse livro inicial da trilogia já possibilita discutir o valor ético da produção de Verissimo ${ }^{1}$.

A opção pela obra do escritor gaúcho é motivada pelo fato de a temática da violência ser muito recorrente nas narrativas que a compõem e porque os textos da trilogia tratam de guerras e conflitos, sendo, assim, a violência um elemento intrínseco às narrativas. Além disso, entendemos que, além do tema ser explorado através da remontagem das revoluções que aconteceram no Rio Grande do Sul, este tema é representado também outras diversas vezes ao longo das narrativas, e de diferentes maneiras, o que amplia a perspectiva de trato da violência na obra do autor. Na esteira dos questionamentos propostos por Jaime Ginzburg (2013), procuramos discutir as seguintes questões: por que a violência é vista como um fenômeno comum? E, adaptando-a para a nossa proposta de investigação, a violência é representada, através dessas narrativas, como um fenômeno comum? Qual o posicionamento crítico, se existente, da obra em relação à violência através da voz do narrador e de personagens? Qual a relação entre representação da violência e construção de uma memória da história do Rio Grande do Sul através da narrativa $O$ continente, de $O$ tempo e $o$ vento? Essa narrativa constrói um elogio da violência no período das revoluções no Estado?

Para isso, propomos uma articulação entre representação da violência e construção de uma memória social, partindo do pressuposto de que a memória construída a partir daquilo que se tem como registro, perpassa, em maior medida, pela lembrança e construção de muitos envolvidos, desde a participação nos acontecimentos à transformação em narrativa e, sobretudo, naquilo que se constrói em sociedade para a formulação de identidades.

A constituição da memória se dá, conforme Maurice Halbwachs (2006), a partir das nossas lembranças unidas à percepção do presente e, segundo o autor, há duas formas de organização das lembranças, uma delas, centrada no próprio indivíduo com suas percepções, que

\footnotetext{
Embora reconheçamos que seria interessante ampliar a reflexão aqui proposta, incluindo os três romances que compõem $O$ tempo e o vento, optamos por abordar apenas o primeiro livro da trilogia por entendermos que ele apresenta elementos suficientes para a reflexão a que nos propomos (uma leitura sobre a representação da violência e construção da memória em uma obra literária brasileira) e ainda por reconhecermos que a narrativa inaugura uma tendência crítica da obra como um todo: incitar o questionamento da violência social através de um trabalho apurado de construção de vozes (de narrador e personagens) que, mostram, por meio de efeitos formais, o quanto pode ser condenado o ato de matar, incitar o litígio e a desarmonia no plano interno do contexto das famílias quanto no externo, no contexto do Estado. Essa percepção nos leva a compreender que o romance de Erico Verissimo opõe-se, de uma forma geral, ao cotidiano trivializado de violência.
} 
seria a memória individual, e outra, inserida em uma sociedade, com ideias compartilhadas, configurando-se na memória coletiva:

Se a memória coletiva tira sua força e sua duração por ter como base um conjunto de pessoas, são os indivíduos que se lembram, enquanto integrantes do grupo. Desta massa de lembranças comuns, umas apoiadas nas outras, não são as mesmas que aparecerão com maior intensidade a cada um deles. De bom grado, diríamos que a memória individual é um ponto de vista sobre a memória coletiva, que este ponto de vista muda segundo o lugar que ali ocupo e que esse mesmo lugar muda segundo as relações que mantenho com outros ambientes. (HALBWACHS, 2006, p. 69)

Neste sentido, e ainda segundo o estudioso, "nossa impressão pode se basear não apenas na nossa lembrança, mas também na de outros" (HALBWACHS, 2006, p. 29). Assim, a memória não se forma apenas acerca das lembranças e percepções individuais, mas a partir da união de diversas vozes que fazem parte da constituição de sentido. Estes colaboradores na constituição da memória podem ter vivenciado os fatos ou serem transmissores das informações que receberam nos grupos com os quais convivem.

À medida que consideramos que a memória pode ser exterior, entendemos também que nem todas as recordações advêm de vivências particulares, podendo, conforme as ideias do autor, serem transmitidas através de outrem, por meio de testemunhos ou de acontecimentos evidenciados através de jornais, livros ou outros elementos que contribuem para a memória de muitas pessoas, ainda que não tenham vivenciado as situações, mas as souberam a partir destes dados. Dessa maneira, ainda que indivíduos não tenham participado ativamente de momentos marcantes ou até mesmo históricos, é possível que esta memória seja resgatada e imbuída entre as suas experiências, uma vez que são diversas as formas de se ter acesso às informações que podem, inclusive, tornarem-se importantes para grupos ou a uma nação, a ponto de consolidarem-se na tradição e incluírem estes mesmos indivíduos em determinados costumes através da identificação com aqueles fatos.

Dentre tantos acontecimentos que permeiam a memória social no contexto brasileiro, há um histórico, já culturalmente estabelecido e frequentador não somente da memória, como da vida de inúmeros grupos, a violência, elemento presente na sociedade como algo do cotidiano e abordado na trilogia de Verissimo. Ao estudar sobre esse tema, lembramos Ginzburg (2013), que enfatiza haver muito a ser discutido diante de toda a violência que habita o mundo de hoje. Nessa perspectiva, interessa observar de que forma o romance de Verissimo constrói uma memória social e cultural acerca dos episódios que aborda na narrativa e qual a relação dessa memória com uma possível política contrária a ações conflitivas e a favor de uma atitude menos contemplativa em relação à violência social, da qual derivam as guerras e revoluções como as retratadas em $O$ continente.

Ginzburg (2013) destaca que, como a violência já é estabelecida juntamente com a construção histórica, cabe refletir, ainda, sobre o impacto traumático das "experiências de barbárie brasileiras" e avaliar o valor estético e ético dos textos literários que se propõem a tematizá-las, o que motiva a discorrer sobre a (ausência) de perspectiva crítica em torno de situações de horror apresentadas por obras literárias brasileiras que associam a violência à nossa história social e também à nossa identidade. Partindo dessas considerações, analisamos o modo como se representa a violência em $O$ continente.

\section{Violência e memória: uma leitura de $O$ continente}

Em 1947, Erico Verissimo iniciou a saga $O$ tempo e $o$ vento, que só concluiu integralmente em 1962, embora a ideia do tema já lhe acompanhasse desde 1939, e os primeiros escritos tivessem surgido em 1941. Com o objetivo inicial de escrever apenas um volume, de aproximadamente 800 páginas, a obra percorreu 15 anos de seu trabalho, ultrapassando 2.200 páginas, divididas em $O$ continente, que remonta a história do Rio Grande do Sul entre 1745 e 1895, $O$ retrato e $O$ arquipélago, que descrevem fatos ocorridos entre 1895 e 1945. De acordo com Sergius Gonzaga, a trilogia de Verissimo consolida um projeto literário do escritor de "recriar ficcionalmente a história da formação do Rio Grande do Sul pastoril por meio da trajetória de sucessivas gerações da família Terra-Cambará" (2004, p. 375). Além disso, segundo destaca o crítico, Verissimo realizou esse projeto através da composição das personagens dessa família, que, com "seus dramas pessoais específicos, vivem de maneira privilegiada os acontecimentos que definem a sociedade sul-rio-grandense." (2004, p. 375). ${ }^{2}$

Cercada de uma ampla bibliografia crítica, a trilogia tem sido apontada por parte da crítica literária como uma obra que permitiu a escritor exteriorizar sua resistência a uma historiografia oficial ensinada nas escolas sobre a formação do Rio Grande do Sul que minimizava traços considerados essenciais, dentre os quais a violência do processo formativo e uma reflexão crítica sobre nossos heróis. Segundo Mara Cristina de Matos Rodrigues,

\footnotetext{
Gonzaga especifica sua afirmação: "Por exemplo: Ana Terra participa da sangrenta e árdua conquista do território, o capitão Rodrigo liga-se à Revolução Farroupilha, Licurgo tem atuação destacada na Guerra Civil de 1893, dr. Rodrigo Cambará é um dos líderes da Revolução de 1930 etc". (2004, p. 375)
} 
$\mathrm{Na}$ origem da trilogia, como visto, havia uma preocupação em relação à abordagem que a historiografia, principalmente a dos livros escolares, fornecia sobre o passado, os heróis, a política e a sociedade sul-rio-grandense. A literatura também contribuía com uma visão idealizada da história do estado, mascarando a violência, a opressão dos heróis sanguinários contra uma população subjugada. (2006, p. 292)

Como podemos perceber, Verissimo registrou sua consciência artística e social ao pensar a trilogia, o que sinaliza também uma postura crítica em relação ao que conta ficcionalmente na obra, que fica evidenciado pela construção das vozes no nos romances. Primeiro volume da trilogia, $O$ continente (1949) trata do surgimento do Rio Grande do Sul e a formação das primeiras cidades, como a fictícia Santa Fé, através das famílias Terra, Caré, Cambará e Amaral. Inicia com os conflitos nos Sete Povos das Missões, ameaçados pela execução do Tratado de Madri, assinado entre portugueses e espanhóis para a entrega do local colonizado pelos jesuítas. Outros conflitos são citados neste primeiro tomo, como a Guerra do Paraguai, a Revolução Farroupilha e a Revolução Federalista, última grande guerra civil do século XIX. Entre as batalhas e a formação sul-rio-grandense, histórias de amor também estão evidenciadas nesta primeira parte da trilogia.

Chama atenção nesse romance o fato de os heróis serem aqueles que vivenciam ou mesmo provocam situações violentas e que estão sempre dispostos a lutar, em qualquer que seja a guerra, para poderem conquistar os ideais almejados. A narrativa de $O$ continente transita por diferentes guerras, de forma mais enfática pela Farroupilha e pela Federalista. É inevitável que os eventos conflituosos culminem em episódios de dor, atrocidades e mortes. Por outro lado, cabe destacar que não somente durante as guerras a violência se apresenta no romance. $\mathrm{O}$ trato com as pessoas, o modo como os mal entendidos se revolvem e a solução para os mais diferentes conflitos de ordem pessoal também têm a violência como pano de fundo, como podemos verificar na descrição de duelos particulares.

Em relação específica à violência, encontramos situações de "extremo horror" e "níveis de sofrimento que não deveriam existir", termos utilizados por Ginzburg (2013, p. 10) quando o autor explica o que acontece em episódios violentos. Evidenciamos isso em $O$ continente a partir da história de Ana Terra, uma das precursoras da família que deu origem a Bibiana e ao Licurgo, personagens muito mencionadas em função das guerras analisadas neste trabalho. Ao realizarmos a leitura da história de Ana Terra, podemos perceber que, ainda sem a presença dos guerrilheiros que seriam considerados heróis por aqueles que cultuam a guerra, e mesmo em uma estância muito longe da civilização, a violência já se fazia muito presente, comprovando mais uma vez este ciclo de pensamentos idênticos que permeiam a geração desta família, que tem seguimento, justamente, com a gravidez de Ana Terra. Esta, ao saber que estava esperando um filho do índio Pedro Missioneiro, recordou: "conhecia casos de pais que matavam as filhas ao sabê-las desonradas. Honra se lava com sangue!" (VERISSIMO, 2013, p. 135-136).

Essa é uma constatação - evidenciando a institucionalização da violência como solução para conflitos das mais diversas origens -, que tem sequência pela continuidade de uma predestinação violenta que marca toda a narrativa e que indica uma clara tendência à "legitimidade" do uso de força e sangue para solução de um conflito familiar. E, se já no século XVIII era o sangue que poderia lavar a honra de uma família, sendo $o$ ato violento concebível como mais correto em relação a outros acontecimentos, com a personagem em questão não foi diferente, como podemos perceber no trecho que segue:

Antônio e Horácio voltaram ao clarear do dia. Estavam pálidos e tinham nos olhos tresnoitados uma apagada expressão de horror. Nada disseram ao entrar; ninguém lhes perguntou nada. Estendida no catre, Ana ouviu o ruído dos passos dos irmãos [...]. Viu quando um deles atirou uma pá no chão. Compreendeu tudo. Numa súbita revolta desejou erguer-se, correr para os irmãos, meter-lhes as unhas na cara, arrancar-lhes os olhos, mas ficou imóvel, sem ânimo para mover-se ou falar. Estava exausta, com um frio de morte no corpo, um vazio na cabeça. Tudo aquilo lhe parecia um pesadelo [...] Ana imaginou Horácio e Antônio cavando uma sepultura, e o corpo de Pedro estendido no chão ao pé deles, coberto de sangue e sereno. Depois os dois vivos atiraram o morto na cova e o cobriram com terra. Bateram a terra e puseram uma pedra em cima. E Pedro lá ficou no chão frio, sem mortalha, sem cruz, sem oração, como um cachorro pesteado. Agora estava tudo perdido. Seus irmãos eram assassinos. Nunca mais poderia haver paz naquela casa. Nunca mais eles poderiam olhar direito uns para os outros. (VERISSIMO, 2013, p. 140-141)

Embora a honra dos Terra pudesse ter sido lavada, a paz da família foi enterrada junto com o índio. Os irmãos horrorizados com seu próprio feito, Ana Terra grávida de um filho sem pai e uma casa onde as pessoas não conversam. A violência realizada para garantir a honra é a mesma que se torna motivo para uma desavença que perdura por muitos anos, gerando, inclusive, anseios de concretização de outra forma de violência, desta vez de Ana, que, revoltada com a atitude dos irmãos, tem 
anseio por arrancar-lhes os olhos, embora não o faça. É através do discurso sutil do narrador que apreendemos o posicionamento de Ana e um certo espanto dos irmãos pelo brutal feito. Ao sentenciar que "Nunca mais poderia haver paz naquela casa. Nunca mais eles poderiam olhar direito uns para os outros", o narrador sugere claramente que as personagens se questionaram - $\mathrm{o}$ ato de matar se justifica nessa circunstância? - e chegaram a uma condenação moral pela ação, pois sua pena seria nunca mais viver em paz.

Dessa forma, a voz narrativa orienta o leitor a uma atitude não contemplativa sobre o conflito a que tem acesso ao ler esse trecho do romance, pois o horror e a perplexidade do homicídio cometido pelos irmãos se intensificam à medida que o narrador opõe os agressores e o agredido. Este é tratado com piedade ("E Pedro lá ficou no chão frio, sem mortalha, sem cruz, sem oração, como um cachorro pesteado"); aquele, com distanciamento emotivo e certo desprezo pela postura hostil. Nesse jogo de oposição, prevalece, em nossa leitura, uma tentativa de resistência do narrador à brutalidade daquilo que narra, percepção que, ampliada ao leitor, corrobora uma concepção de obra literária combativa e contrária à reprodução de barbáries. Através desta narrativa fictícia, podemos compreender o que afirma Ginzburg (2013) ao promover uma reflexão sobre a postura ética da literatura e a necessidade de que se defenda que a violência não se justifica em nenhuma das hipóteses, já que causa, em medidas ainda maiores, a destruição.

Neste mesmo sentido, encontramos em $O$ continente outra passagem que incita uma percepção sobre o valor ético e social do romance. Trata-se do ataque dos castelhanos à estância dos Terra. Embora o Brasil estivesse vivenciando as consequências da Revolução Francesa e Inconfidência Mineira - mais uma vez a guerra como pano de fundo do sofrimento -, o ataque dos castelhanos àquela família, matando todos os homens e violentando Ana Terra, estaria colocando atos violentos como necessários para a conquista de bens materiais:

Um suor gelado escorria-lhe pela testa, entrava-lhe nos olhos, fazendo-os arder e aumentando-lhe a confusão do que via: o pai e o irmão ensanguentados, caídos no chão, e aqueles bandidos que gritavam, entravam no rancho, quebravam móveis, arrastavam a arca, remexiam nas roupas, derrubavam a pontapés e golpes de facão as paredes que ainda estavam de pé. Mas não lhe deram tempo para olhar melhor. Começaram a sacudi-la e a perguntar: - Donde está laplata? laplata... laplata... laplata... Ana estava estonteada. Alguém lhe perguntava alguma coisa. Dois olhos sujos e riscados de sangue se aproximaram dos dela. Mãos the apertavam os braços. [...] Braços enlaçaram-lhe a cintura e Ana sentiu contra as costas, as nádegas, as coxas, o corpo duro dum homem; e lábios úmidos e mornos se lhe colaram na nuca, desceram em beijos chupados pelo cogote, ao mesmo tempo que mãos lhe rasgavam o vestido. [...] Ela soltou um grito, fez um esforço para se erguer mas não conseguiu. $\mathrm{O}$ homem resfolgava, o suor de seu rosto pingava no de Ana, que lhe cuspia nas faces, procurando ao mesmo tempo mordê-lo. (Por que Deus não me mata?) Veio outro homem. E outro. E outro. E ainda outro. Ana já não resistia mais. Tinha a impressão de que lhe metiam adagas no ventre. Por fim perdeu os sentidos. (VERISSIMO, 2013, p. 156-157).

A busca pelo dinheiro, através do roubo, que já pode ser considerada uma forma de violência não vem sozinha. Além do ato de roubar, é notório que as personagens que representam os castelhanos fazem graça da situação, ao matar toda a família e deixar a mulher horrorizada e, ainda, ao abusar dela com o objetivo da satisfação física, por meio do estupro coletivo da personagem ${ }^{3}$. Cabe registrar ainda que Ana vive uma experiência limite marcada pela prática sucessiva de violência sexual, o que a aproxima do desejo de morte ("Por que Deus não me mata?" e "Por fim perdeu os sentidos"), numa alusão à constituição negativa do sujeito, que, impossibilitado de defender-se e desvencilhar-se da força masculina que a oprime e machuca, rende a optar pela finitude da vida em função da consciência de entrar numa batalha perdida. Ao acentuar o cansaço da personagem e sua desistência, por falta de forças, em resistir aos ataques sexuais, o narrador muda sua "câmera" e passa a focar a subjetividade abalada da mulher, criando uma perspectiva narrativa que se solidariza com o agredido e condena o agressor. Entendemos que essa postura do narrador, que se contrapõe à visão das personagens agressoras, no caso, os homens da cena, é um indício formal do romance que sinaliza não só uma consciência do autor sobre as diversas facetas de violência social presentes no processo de formação do Rio Grande do Sul, mas também uma tentativa de registrar danos no corpo e na alma daqueles que vivenciam situações de opressão e crueldade, e isso sem dúvida interfere na capacidade de percepção e elaboração dos eventos históricos.

No romance, também a violência que não provém de batalhas institucionalizadas é representada, assim como a guerra, como uma forma de resolver todos os conflitos. Isso acontece, por exemplo, quando Rodrigo dirige-se ao coronel Amaral para avisar que ficará na cidade e o

\footnotetext{
Esta graça que citamos pode ser notada ainda mais explicitamente em outros trechos da narrativa, quando, por exemplo, o capitão Rodrigo chega à cidade de Santa Fé e com sua expressão: "nos pequenos dou de prancha e nos grandes dou de talho" (VERISSIMO, 2013, p. 209), brinca com a questão da violência antes mesmo de se apresentar aos demais homens que compõem a cena. Como os atos violentos e a cultura de guerra já estão enraizados naquele lugar, um até então desconhecido já desafia para que a briga de fato se suceda. Sem motivos, sem inimizades, sem guerra constituída, há a ideia de duelar, pelo simples fato de duelar
} 
mesmo pega sua adaga, convidando à briga, já que não simpatiza com o novo habitante do lugar. E é também através de duelo que o capitão resolve suas diferenças com o pretendente de Bibiana, o Bento Amaral:

- Podemos resolver tudo isso amigavelmente - disse o padre, com voz um pouco trêmula. - Vamos, rapazes. No fim de contas não há motivo. Bento Amaral interrompeu-o:- Com certos tipos a gente só resolve as coisas de homem pra homem. Os outros admiravam-se da serenidade de Rodrigo, que encarava Bento a sorrir. [...] O padre Lara tinha os lábios trêmulos e sua respiração parecia mais agoniada que nunca.-Meninos, acho que podíamos ajustar tudo honradamente sem ser necessário um duelo - sugeriu. - Agora é tarde, padre! - gritou Rodrigo. - Se eu não botar minha marca na cara dessecachorro, não me chamo mais Rodrigo Cambará.[...] - Arma de fogo? - perguntou Rodrigo. - Adaga. Os olhos de Rodrigo brilharam. - É melhor. Leva mais tempo. (VERISSIMO, 2013, p. 274-277).

O padre, mais uma vez aparece como a voz que questiona e tenta encontrar outra solução que não necessite perpassar por uma briga. Contudo, os dois demonstram o grande interesse no duelo, até mesmo pela escolha da arma que causará mais dor. E a tranquilidade expressa por Rodrigo evidencia, novamente, o modo como algumas das personagens da ficção tratam a violência como algo jocoso.

Estes mesmos pressupostos podem ser verificados em outros dois momentos da narrativa que selecionamos como exemplo: um, em que personagens falam acerca do modo como Dr. Aguinaldo Silva, um novo morador da cidade, matou a sua esposa e o amante dela, e o outro, relativo ao enforcamento de um escravo acusado de roubo:

Havia no drama um detalhe dum trágico grotesco que os maldizentes usavam como remate humorístico do caso: "O homem estava começando a tirar a roupa quando Aguinaldo saiu de baixo da cama. O infeliz nem teve tempo de dizer ai: a faca do marido rasgoulhe o bucho". Risadas. "No fim, acho que ele não sabia se segurava as calças ou as tripas." Pausa dramática. "Mas tanto as calças como as tripas acabaram caindo no chão.” Novas risadas. (VERISSIMO, 2013, p. 20)

Neste caso, é a voz do narrador que questiona as risadas, tratando como trágico o motivo que suscita o riso. A respeito de discursos desta natureza, Ginzburg (2013) afirma ser importante este papel do narrador, uma vez que, ele mesmo, pode fazer conhecer diferentes perspectivas. No outro episódio que citamos, cujo fragmento será exposto a seguir, não é a voz do narrador que questiona de maneira mais evidente, mas existem personagens incumbidas de pensar e transmitir o horror da violência, registrando uma perplexidade diante da experiência:

Bolívar não respondeu. O suor fazia arder-lhe as faces recém-escanhoadas e uma dor latejante na cabeça deixava-lhe as ideias confusas. - Ele anda triste por causa do Severino - explicou Florêncio.Estavam agora os três a menos duma quadra da praça e já podiam ver o movimento das pessoas que procuravam lugares em torno da forca. Lenços, roupas e vozes alegres ao sol - aquilo parecia uma festa. [...] Um homem achava-se sentado numa pedra, alisando uma palha de milho com as costas da faca. Era o Chico Carreteiro. Ao ver o grupo o caboclo dirigiu-se a Bolívar e caçoou: - Então vamos ter hoje dois enforcamentos ao mesmo tempo, não? Mostrou os dentes escuros num sorriso rasgado. Bolívar teve vontade de atirar-se sobre ele e partir-lhe a cara a bofetadas. Cerrou os punhos, olhou duro para a frente e não respondeu. Bibiana, porém, sorriu para o carreteiro e disse: - É verdade, Chico, é verdade. - É preciso ser muito malvado pra gozar com o sofrimento alheio - observou Florêncio em voz baixa, olhando as pessoas que disputavam lugares ao redor de cadafalso. Tirou o relógio do bolso e olhou o mostrador. - E ainda falta mais duma hora! (VERISSIMO, 2013, p. 63).

Assim como a guerra fora tratada como uma festa, um fandango, também aqui um ato de extrema violência, o enforcamento de um homem, é considerado como tal. Existem algumas personagens que apresentam aversão a este episódio, mas existem, ainda, aqueles que esperam ansiosamente pelo momento do enforcamento e, ainda, os que conseguem criar piadas em cima do sofrimento alheio. A violência, neste sentido, é representada como um espetáculo, no qual os expectadores assumem os mais diferentes papéis. Embora, num primeiro momento, essa abordagem do espetáculo da violência possa ser vista como um suposto elogio à crueldade no romance, isso não se confirma quando levamos em consideração todo o contexto narrativo. A existência do embate de vozes entre personagens, em nossa leitura, é um dos recursos explorados por Verissimo para romper com uma visão automatizada da violência como algo natural e a ser aceito e legitimado em todos os espaços sociais. A presença de vozes conflitivas é, nessa linha de raciocínio, o elemento articulador da postura ética do escritor e do valor social da obra como texto literário que combate o conflito e atual em prol da pacificidade. Tal perspectiva se amplia na medida em que observamos o perfil das personagens mulheres.

Contrapondo com as personagens femininas que questionam ou, pelo menos, não concordam com as atrocidades acometidas pelas guerras, como vimos que acontecia durante a revolução, existem outras mulheres que fazem parte deste ciclo violento. Para Chaves 
(1981), a verdadeira guerra de $O$ continente foi travada, principalmente, entre Bibiana, agora com mais idade e após ter vivenciado inúmeros episódios de guerras e perdas, e Luzia, a esposa do seu filho Bolívar. Sogra e nora vivem em conflito, uma desavença que inicia pela compreensão de Bibiana a respeito do Sobrado onde Luzia mora com seu avô. A personagem entende que a casa pertence à família Terra Cambará, já que o terreno foi tirado de seu pai, que tinha uma pequena residência onde ela e os irmãos cresceram. Para Bibiana, casar seu neto com Luzia é o mesmo que "tomar" o Sobrado de volta, não através de uma guerra física, mas travando episódios conflituosos diários entre as duas. Esta saga de ódio é ainda ampliada quando se percebe que Luzia é doente, mas a doença da personagem também não é física. A moça sente prazer com a dor alheia. Remetendo novamente ao enforcamento do escravo, sob a perspectiva de Luzia, podemos constatar esta afirmativa:

- Uma vez na Corte, quando eu era menina, vi um enforcamento. Ah! Mas foi muito mais bonito que este. Enfim, Santa Fé é apenas uma vila. Não pode se comparar com o Rio de Janeiro, é natural. [...] Ind'agorinha eu vi tudo ali da janela - disse Luzia, parando de tocar e descansando as mãos no regaço. Seus olhos pousaram no rosto do vigário. -Vosmecê ouviu quando o pescoço do negro se quebrou? - Se ouvi? perguntou o padre, franzindo a testa. - Quero dizer, ouviu o barulho de ossos se quebrando? O sacerdote encolheu os ombros, em dúvida. - E ele ficou de língua de fora? - Minha filha... eu... vosmecê sabe que a gente não presta bem atenção a essas coisas. $\mathrm{Na}$ hora se fica tão... Ora, pra falar a verdade, nem olhei quando puxaram o alçapão. Estava de olhos fechados, rezando. Luzia insistiu: - Mas depois, quando vosmecê olhou... ele estava de língua de fora? O padre voltou a cabeça para Aguinaldo e disse com um sorriso constrangido: - A curiosidade das moças de hoje não tem limites. No espírito de Winter a palavra curiosidade transformou-se em crueldade. Luzia positivamente tinha a coragem de sua crueldade. Agora a névoa se havia dissipado ao redor dela. Lá estava a Musa da Tragédia com toda a sua alma desnudada. [...] O padre Otero olhava fixamente para o seu cálice de licor.Tinha a testa franzida, o ar preocupado. - Que bicho lê mordeu, padre? - perguntou Aguinaldo. - Ficou impressionado com a coisa? - No fim de contas, não foi nenhuma festa... - replicou o sacerdote. (VERISSIMO, 2013, p. 82).

A curiosidade exposta de Luzia demonstra o grande interesse da noiva de Bolívar em saber detalhes sobre o enforcamento daquela pessoa, já que ela presenciou um outro, muito mais "bonito" do que este em outra oportunidade. A personagem atribui uma qualidade positiva a um fato de extrema violência, e, para ela, o negativo desta situação seria, na realidade, a pequena dimensão que, em sua opinião, o fato estava recebendo. É mais uma vez a figura do sacerdote que questiona tanto o fato ocorrido quanto o gosto da moça por tudo aquilo que acontecia. Esse prazer de Luzia diante da dor alheia aparece, inclusive, quando seu avô está à beira da morte. A jovem não se afasta do homem e o observa atentamente "como se não quisesse perder um minuto sequer daquela lenta agonia.[...] Ela estava gozando aquele momento. Tinha a respiração ofegante e um brilho meio embaciado nos olhos claros" (VERISSIMO, 2013, p. 92). Em situação semelhante, quando viaja com o já marido para Porto Alegre, Luzia quer sempre ficar um pouco mais na cidade que está assolada pela cólera que mata inúmeras pessoas dia após dia:

Eu andava desnorteado, desconfiava da água que bebia, das coisas que comia. Não podia dormir de noite. Sentia por todos os lados cheiro de morte, de podridão. Mas Luzia andava contente. Ficava na janela olhando as pessoas que caíam na rua. Às vezes ia pra fora pra esperar a carroça que vinha recolher os defuntos, ia olhar de perto a cara deles... Uma vez chegou a entrar numa casa onde estavam velando um morto; não conhecia ninguém mas foi direito ao caixão e tirou o lenço da cara do defunto e ficou olhando. Fazia todas essas coisas mas de noite, na cama, tremia e chorava de medo. E quando eu convidava pra vir embora, ela não queria. 'Só mais uns dias, Boli' - ela dizia - 'só mais uns dias'. (VERISIMO, 2013, p. 150).

Esse prazer pelo sofrimento alheio, representado na obra de Verissimo, pode enquadrar-se na perspectiva de Ginzburg (2013, p. 43), que explica como na literatura podemos encontrar o comportamento violento enquanto causador de prazer e satisfação. Vemos esta perspectiva quando a personagem Luzia sente satisfação no sofrimento do outro, seja através da doença que o destrói, tendo em si mesma o caráter violento, ou, pela violência causada de uns para com os outros, como no caso do enforcamento.

Embora Luzia seja representada de forma a sentir este prazer de modo muito explícito, podemos entender que as demais personagens do romance, envolvidas com episódios conflituosos, também sentem prazer com a prática violenta. Os castelhanos, ao atacarem a estância buscando dinheiro, matam e violentam por prazer. Os duelos e brigas desafiadoras a qualquer momento, entre homens que ao menos se conhecem ou que não têm motivos para iniciar uma batalha antes mesmo de uma conversa também são recorrentes ao longo da narrativa. Além disso, vimos a preferência pela adaga em vez da arma de fogo, pelo prazer de ver a demora no sofrimento do outro, e o brilho no olhar do capitão Rodrigo ao chegar a esta conclusão. Da mesma forma, quando observamos o modo como a guerra é representada, entendemos o quanto 
a revolução era importante inclusive para o divertimento de algumas das personagens. Todos estes exemplos levam à crença de que não somente Luzia, que notoriamente vibra com o sofrimento alheio, mas sim outras representações na trama apresentam a violência com o viés da satisfação.

Por outro lado, vemos, diversas vezes, as figuras que surgem para questionar as práticas violentas, para inclusive, algumas vezes, propor práticas diferenciadas. Contudo, nenhuma das personagens chega a agir de modo a impor o fim efetivamente das ações violentas. Embora reflitam e até expressem opiniões contrárias às práticas conflituosas, as personagens do romance acabam conformando-se com as situações e opiniões dos demais, não apresentando atitudes em relação aos episódios desenvolvidos.

Ginzburg (2013, p. 43) afirma que "a presença constante de práticas violentas em nossa história estaria associada ao fato de que existe prazer no movimento agressivo". Se a literatura e, especificamente, $O$ continente, apresentam estes episódios é porque, de fato, a história da vida humana é marcada por situações deste cunho que, representados através do romance, e com o teor ficcional, ganham um novo sentido capaz de proporcionar releituras e ampliar o sentido da humanização, justamente, diante da leitura das práticas do horror.

Com perspectiva semelhante, e considerando o romance de Verissimo como uma narrativa que remonta uma história, recorremos a Walter Benjamin (1994, p. 224), que afirma que "articular historicamente o passado não significa conhecê-lo 'tal como ele de fato foi'. Significa apropriar-se de uma reminiscência, tal como ela relampeja no momento de perigo". Desta maneira, compreendemos que a memória representada nas narrativas registra os fatos, mas é acrescida de informações atualizadas de acordo com o tempo de agora, o que permite não só melhor compreender o passado, mas atuar para que barbáries não sejam repetidas.

Desta maneira, podemos unir a reflexão sobre a representação da violência em $O$ continente à questão da memória, se pensarmos a história representada não unicamente a partir dos fatos como eles são, mas, em maior medida, através de outros aspectos que podem contribuir com a formação de uma memória coletiva mais crítica, com novas possibilidades de reflexão. Em um país como o nosso, em que há uma grande dificuldade em esclarecer episódios do passado, como o da Ditadura, do processo escravista e do Estado Novo, por exemplo, e uma tendência ao conservadorismo que impede o questionamento ou a revisão do "já estabelecido", torna-se fundamental investigar pontos e contrapontos da narração de eventos históricos, e a nossa literatura tem contribuído bastante para elucidar a nossa história. Isso porque, além de ser uma representação do social, a literatura dialoga com a sociedade, recria-a e a molda de modo a propor uma leitura ou várias leituras de um mesmo fato. Isso revela ainda o quanto o pensamento criativo de nossos escritores traduz uma consciência individual e também coletiva de nosso passado e da forma como um determinado evento ocorreu, o que contribui para a construção de uma memória que põem em xeque determinadas versões "oficiais" de episódios históricos.

Nesse sentido, a memória pode ser constituída, segundo alerta Halbwachs (2006), também a partir de leituras. No caso de $O$ continente, há a memória individual de cada personagem e a do narrador que, juntas, constroem uma memória que representa uma certa consciência de grupo em relação ao processo de formação do Rio Grande do Sul. Aos olhos da obra de Verissimo, episódios violentos e a guerra em si devem ser rememoradas não a fim de enaltecer estes feitos, ao contrário, esta memória que passa a fazer parte da coletividade representada pelas diversas vozes do romance teria como uma das funções trazer à tona uma discussão que é pertinente enquanto construção de um novo pensamento social: impedir que a violência se perpetue e que barbáries sejam replicadas.

Neste sentido, ao abordar sobre o esquecimento em torno das recordações de Auschwitz, Adorno (1995) apresenta a ideia que aquilo que é posto deve ser contrário ao esquecimento. A partir disso, entendemos que para ser proporcionada uma reflexão através da memória perpassada pelas das obras, não é cabível que os fatos sejam atenuados. "Quem ainda insiste em afirmar que o acontecido nem foi tão grave assim já está defendendo o que ocorreu" (ADORNO, 1995, p. 136), por outro lado, é necessário que os episódios sejam expostos, não de maneira sensacionalista ou trivial, mas com vistas a contribuir para a formação de uma memória coletiva que não vislumbre a glorificação de fatores de desumanização.

Se a memória social é, portanto, permeada por episódios de guerra e violência, $O$ continente traz a possibilidade de registrar ficcionalmente alguns episódios, podendo estimular que esta memória construída coletivamente possa estar mais voltada à preocupação com o que fazer, do que simplesmente em conhecer os fatos como eles são. No campo da literatura, a memória precisa ser construída com a inclusão de obras até então não pertencentes ao cânone, que é amparado pela visão da tradição, e que possam oportunizar um contraponto ao que até então é tido como "oficial', já que, como enfatiza Ginzburg (2012, p. 217), "como parte substancial de nossa memória coletiva, o cânone literário, que resguarda um patrimônio cultural identificado como referência de valores estéticos, está ainda, em grande parte, expressando os interesses da tradição patriarcal".

Nessa perspectiva, $O$ continente, apesar de registrar valores da cultura patriarcal e representar um 
comportamento de violência que acompanhou a formação do Estado do Rio Grande do Sul e durante muito tempo caracterizou o modo de ser gaúcho, não apresenta em seu discurso um elogio à crueldade dos fatos históricos ou argumento baseado em causa e efeito para justificar as barbáries registradas na matéria literária. Ao contrário, ao recompor uma memória coletiva da história que representa, o romance atualiza o passado, ressignificando-o. A autora Jeanne Marie Gagnebin (2006, p. 39) questiona sobre por que o resgate do passado é tão mencionado hoje. E dentre suas afirmativas, acrescenta: "Pode-se escrever uma história da relação do presente com a memória e o passado, uma história da história, por assim dizer, o que já foi iniciado por vários autores". Sendo assim, entendemos que a obra de Verissimo, muito além de resgatar o passado, faz a sua contribuição para a o resgate desta história enquanto possibilidade de reflexão para, a partir disso, tornar constituinte a memória coletiva. A mesma autora escreve ainda sobre a existência de uma "memória ativa que transforma o presente" (GAGNEBIN, 2006, p. 59).

A narrativa em $O$ continente, por um lado, trata a violência sim como algo comum. A violência, no romance, é quase inerente à vida e às atitudes das personagens, promovendo suas visões de mundo, suas vivências e as escolhas que tomam. Por outro lado, as vozes que questionam a violência e as consequências decorrentes das atitudes violentas vêm à tona para fazer pensar acerca do modo como os fatos poderiam ter sido resolvidos senão através de conflitos. Uma vez postas estas considerações, retomamos o pensamento acerca da memória coletiva enquanto transformadora do presente se relacionarmos o que nos traz a obra com os acontecimentos que permeiam o mundo ou, de modo mais específico, o Brasil e o Estado do Rio Grande do Sul hoje.

O romance de Verissimo, ao trazer este questionamento, principalmente sobre as consequências de escolhas violentas, pode contribuir para que, a partir de uma história passada, sejam repensadas as ações do presente. Entretanto, não cabe somente à literatura o papel de atualizar as percepções dos indivíduos. Ainda que contribua para a formação de uma memória coletiva mais crítica, a história de guerras e violência no Rio Grande do Sul continua permeando a memória social enquanto orgulho por seus heróis que guerrearam e lutaram pela terra e por liberdade, diferente do que pudemos constatar nesta primeira parte da trilogia que analisamos, que, embora traga o aspecto vultoso dos heróis rio-grandenses, apresenta muito mais sobre suas falhas, sobre o seu lado desmitificado e, especialmente, sobre até onde pode levar os seus anseios e práticas de guerra e violência.

Ainda diante da memória enquanto constituinte de modificações no presente, podemos conferir, mais uma vez, as percepções de Adorno (1995, p. 46): "No fundo, tudo dependerá do modo pelo qual o passado será referido no presente; se permanecemos no simples remorso ou se resistimos ao horror com base na força de compreender até mesmo o incompreensível". É na atualização de fatos que, cultural e naturalmente, poderiam fazer parte de determinados grupos, que se torna possível a compreensão hoje e, a partir disso, a modificação na forma de identificá-los, tratando da guerra e violência não como institucionalizado, mas classificando-os como valor negativo, a fim de trazer à tona o horror proporcionado por estes atos ao invés de permanecer na impassibilidade.

\section{Considerações finais}

Se a memória se constrói também a partir de outras percepções e não apenas de lembranças individuais, as obras literárias são, indiscutivelmente, grandes colaboradoras da construção e formação da memória social. Investigar estas artes não apenas traz à tona grandes temas que ainda merecem ser amplamente discutidos, como proporciona novas formas de interpretar as pessoas, o mundo e a própria história social.

Ao abordarmos a constituição da memória a partir da representação da violência, é preciso também destacarmos a importância daquilo que se publiciza. A representação de fatos através de obras de arte pode trazer elementos que, embora não façam parte de fatos reais, podem proporcionar novos modos de pensar a respeito das temáticas abordadas. Nesse sentido, Jaime Ginzburg (2013) destaca o papel da literatura no debate de temas sociais e aponta a grande importância da reflexão sobre violência na sociedade brasileira. Segundo o autor, a violência não é justificável em nenhuma hipótese e, através da análise do discurso literário, torna-se possível, por exemplo, refletir sobre o que motiva as personagens a agirem de forma violenta. Dessa forma, a avaliação da ação das personagens e também do narrador que as apresenta conduz a uma percepção sobre a estética e a ética nas produções de nossa literatura. Isso, por extensão, ajuda-nos a formar um juízo crítico sobre a qualidade da obra e seu potencial de reflexão sobre temas e problemas sociais de grande relevância em nosso contexto e ainda construir uma memória acerca de diferentes episódios de nossa história social.

Tendo isso em vista, consideramos que a memória coletiva que $O$ continente busca resguardar, a partir da representação da violência, é justamente formada a partir de uma releitura atualizada deste passado, que pode ser mais uma vez lido, sob o viés ficcional, e sob diferentes pontos de vista, para que cada um dos receptores possa constituir suas percepções acerca daqueles fatos e ainda, compor as suas inquietações e indagações no presente. Ainda que predominem no romance personagens que têm 
a guerra e a violência como inerentes ao seu modo de vida e que incitem uma valorização positiva do conflito, são apresentadas, durante o romance, as consequências destas escolhas, como mortes, famílias destituídas, violência e perdas, o que institui um contraponto a uma visão mais passiva de aceitação da guerra e da violência como algo natural e como fato a não ser passível de questionamento.

É importante ressaltar, nessa linha de raciocínio, que parece que o ciclo da trilogia, que perpassa pelas gerações de homens que lutam na guerra e de mulheres que os esperam voltar, não é o único que está presente na narrativa. Existe um ciclo que perfaz a pacificação, já que as personagens que questionam não parecem sair do seu lugar: refletem, sugerem, mas as atitudes para a modificação das realidades são poucas ou quase nulas. Embora sejam levantadas possibilidades de se fazer diferente ou, ainda, existam discussões sobre os acontecimentos violentos, a conformidade é um fator predominante, como se guerra e violência fossem inerentes à saga da família, da cidade, do estado e do país. Em outras palavras, notamos que em algumas personagens há uma percepção em relação ao horror da violência e da guerra, mas não há ação para contê-las, o que nos permite pensar que o ímpeto de resistência do romance aos conflitos está no nível de uma proposição reflexiva e não de uma atitude de resignação com vistas a uma mobilização a favor da pacificação.

$\mathrm{E}$, se por um lado, consideramos um interesse em que obras e escritores assumam um posicionamento ético de combate à violência, por outro, não podemos ignorar que a construção de uma memória social de episódios de nossa história e a presença de vozes que de certa forma se conflitam em relação à guerra faz do romance de Erico Verissimo uma obra atenta a violência de seu tempo. Isso porque, entre os ciclos de apologia a guerras e os de inconformidade em relação a elas, existe uma linha tênue que pode levar o leitor a torcer pelos ditos heróis ou a questioná-los, e, ao propor isso, o texto do escritor gaúcho já cumpre um grande papel de relevância ética, estética e social que torna o romance uma narrativa merecedora de atenção da crítica especializada.

\section{Referências}

ADORNO, Theodor W. Educação e emancipação. Trad. Wolfgang Leo Maar. Rio de Janeiro: Paz e Terra, 1995.

BENJAMIN, Walter.Sobre o conceito de história. Magia e técnica, arte e política: ensaios sobre literatura e história da cultura. Trad. Sérgio Paulo Rouanet. São Paulo: Brasiliense, 1994. p. 222-232.

CHAVES, Flávio Loureiro. Erico Verissimo: realismo \& sociedade. 2. ed. Porto Alegre: Mercado Aberto, 1981.

GAGNEBIN, Jeanne- Marie. Lembrar, escrever, esquecer. São Paulo: Editora 34, 2006.

GINZBURG, Jaime. Literatura, violência e melancolia. Campinas, SP: Autores Associados, 2013.

GINZBURG, Jaime. Crítica em tempos de violência. São Paulo: Editora da Universidade de São Paulo/Fapesp, 2012.

GONZAGA, Sergius. Curso de literatura brasileira. Porto Alegre: Leitura XXI, 2004.

HALBWACHS, Maurice. A memória coletiva. Trad. Beatriz Sidou. São Paulo: Centauro, 2006.

PELLEGRINI, Tânia. As vozes da violência na cultura brasileira contemporânea. Crítica marxista, 2005. Disponível em: <www. unicamp.br/cemarx/criticamarxista/critica21-Apelegirni.pdf>. Acesso em: 18 mar. 2012.

RODRIGUES, Mara Cristina de Matos. O tempo e o vento: literatura, história e desmitificação. MÉTIS: história \& cultura, Caxias do Sul, v. 5, n. 9, p. 289-312, jan./jun. 2006. Disponível em: <www.ucs.br/etc/revistas/index.php/metis/article/ download/794/558 >. Acesso em: 14 dez. 2015.

Recebido: 30 de abril de 2015 Aprovado: 16 de dezembro de 2015 Contatos: bisol@uri.edu.br luana@uri.edu.br 